\title{
Effect of Sieving on Ex Situ Soil Respiration of Soils from Three Land Use Types
}

\author{
Adetunji Alex Adekanmbi ${ }^{1} \cdot$ Liz J. Shaw $^{1} \cdot$ Tom Sizmur $^{1}$ (I)
}

Received: 23 August 2019 / Accepted: 7 January 2020 / Published online: 22 January 2020

(C) The Author(s) 2020

\begin{abstract}
This study aims to investigate the effect of sieving on ex situ soil respiration $\left(\mathrm{CO}_{2}\right.$ flux $)$ measurements from different land use types. We collected soils $(0-10 \mathrm{~cm})$ from arable, grassland and woodland sites, allocated them to either sieved (4-mm mesh, freshly sieved) or intact core treatments and incubated them in gas-tight jars for 40 days at $10^{\circ} \mathrm{C}$. Headspace gas was collected on days $1,3,17,24,31$ and 38 and $\mathrm{CO}_{2}$ analysed. Our results showed that sieving $(4 \mathrm{~mm})$ did not significantly influence soil respiration measurements, probably because micro aggregates $(<0.25 \mathrm{~mm})$ remain intact after sieving. However, soils collected from grassland soil released more $\mathrm{CO}_{2}$ compared with those collected from woodland and arable soils, irrespective of sieving treatments. The higher $\mathrm{CO}_{2}$ from grassland soil compared with woodland and arable soils was attributed to the differences in the water holding capacity and the quantity and stoichiometry of the organic matter between the three soils. We conclude that soils sieved prior to ex situ respiration experiments provide realistic respiration measurements. This finding lends support to soil scientists planning a sampling strategy that better represents the inhomogeneity of field conditions by pooling, homogenising and sieving samples, without fear of obtaining unrepresentative $\mathrm{CO}_{2}$ flux measurements caused by the disruption of soil architecture.
\end{abstract}

Keywords $\mathrm{CO}_{2}$ flux $\cdot$ Respiration $\cdot$ Homogenisation $\cdot$ Land use $\cdot$ Disturbance

\section{Introduction}

$\mathrm{CO}_{2}$ flux from soil not containing plant roots represents the heterotrophic respiration of soil organisms (Gabriel and Kellman 2011). Soil respiration releases more $\mathrm{CO}_{2}$ into the atmosphere annually than all anthropogenic sources combined (Marland 2008) and a small change in $\mathrm{CO}_{2}$ flux from soils, globally, can greatly alter the concentration of atmospheric $\mathrm{CO}_{2}$ and influence our climate (Schurgers et al. 2018). Measurement of soil respiration is therefore important for quantifying the flux of $\mathrm{CO}_{2}$ to the atmosphere from soils. Soil $\mathrm{CO}_{2}$ flux also represents the activity of soil biological communities, thereby serving as a valuable indicator of soil health (McGowen et al. 2018).

Soil respiration measurements undertaken in the field and laboratory often yield contrasting results (Davidson et al. 1998). $\mathrm{CO}_{2}$ flux measured at a single location in situ may

Tom Sizmur

t.sizmur@ reading.ac.uk

1 Department of Geography and Environmental Science, University of Reading, Reading, UK not be representative due to soil heterogeneity at the field scale. Excavation of soil, followed by ex situ measurement of soil respiration under controlled conditions, is often performed to compare soils or test specific hypotheses (Gutinas et al. 2013; Zhou et al. 2014; Bao et al. 2016; Yan et al. 2017), while minimizing confounding factors. Whereas in situ measurements are more representative of the actual field conditions (Gabriel and Kellman 2011), ex situ measurements can be used to apply treatments in a systematic manner and are thus very useful. Soil respiration can be measured ex situ on intact cores (Hangs et al. 2016; Meyer et al. 2019), fresh soil sieved with mesh sizes ranging $2 \mathrm{~mm}$ to $5 \mathrm{~mm}$ (Thomson et al. 2010; Datta et al. 2014), or (most frequently) air-dried soil sieved to $2 \mathrm{~mm}$ (Mathur and Sanderson 1978; Valerie and Cook 1983; Thuries et al. 2000; Thomson et al. 2010; McGowen et al. 2018). Sieving and homogenisation prior to incubation (often favoured by researchers to create replicates appropriate for statistical analysis) disrupt the original architecture of the soil experienced by decomposer organisms (Baveye et al. 2018) and may influence the soil respiration measurement. Few studies have previously examined the effects of sieving on soil respiration. While one of them (Stenger et al. 2002) revealed no significant differences in glucose-C 
mineralisation between intact and sieved soil, another (Herbst et al. 2016) observed that air-drying and sieving influenced the nature of the relationship between soil moisture and soil respiration.

It is often believed that disturbing soil by sieving will expose occluded organic matter to microbial degradation and break fungal hyphae, thereby generating a flush of $\mathrm{CO}_{2}$ (Datta et al. 2014). We aimed to assess the effect on soil respiration of sieving soils collected from a woodland, a grassland, and an arable field representing the major land uses in the UK (Table 1). We hypothesised that sieving would increase short-term soil respiration and that this difference would be greater for soils less affected by previous physical disturbance (i.e. woodland soils).

\section{Materials and Methods}

Twelve soil cores were collected using $98 \mathrm{~cm}^{3}$ bulk density rings (inner diameter $5 \mathrm{~cm}$, height $5 \mathrm{~cm}$ ), similar to that used by Comeau et al. (2018), from woodland (latitude $51^{\circ} 28.678^{\prime}$, longitude $000^{\circ} 53.739^{\prime}$ ), grassland (latitude $51^{\circ} 28.564^{\prime}$, longitude $000^{\circ} 54.198^{\prime}$ ) and arable (latitude $51^{\circ} 28.577^{\prime}$, longitude $000^{\circ}$ $53.970^{\prime}$ ) soils on the University of Reading research farm at Sonning, Berkshire, UK. Sonning soils are classified as Chromic Endoskeletic Luvisols, containing freely draining slightly acidic loamy soils predominantly and the site location matches Sonning 2 soils' description (Cranfield University, 2019) which is flinty coarse loamy soil over a gravelly typical paleo-argillic brown earth. The three land uses represent the most common land use types in the UK and around the world. While the grassland is mainly used for grazing by dairy cattle, the arable

Table 1 Location and physical and chemical properties of the three different soils from different land uses

\begin{tabular}{|c|c|c|c|}
\hline & & Land use & \\
\hline & Arable & Grassland & Woodland \\
\hline Easting & 476,503 & 476,187 & 476,710 \\
\hline Northing & 175,919 & 175,861 & 176,060 \\
\hline$\%$ sand $(50-2000 \mu \mathrm{m})$ & 41.46 & 43.01 & 51.11 \\
\hline$\%$ silt $(2-50 \mu \mathrm{m})$ & 50.46 & 48.86 & 40.76 \\
\hline$\%$ clay $(<2 \mu \mathrm{m})$ & 8.08 & 8.14 & 8.13 \\
\hline Texture & Silt loam & Loam & Loam \\
\hline$\%$ water holding capacity & $48.88(1.11)$ & $55.00(1.05)$ & $40.54(0.87)$ \\
\hline $\mathrm{pH}$ in water & $6.30(0.02)$ & $6.23(0.37)$ & $3.86(0.03)$ \\
\hline $\mathrm{NO}_{3}-\mathrm{N}\left(\mathrm{mg} \mathrm{g}^{-1}\right)$ & $13.48(1.56)$ & $6.32(0.73)$ & $12.52(1.40)$ \\
\hline $\mathrm{NH}_{3 \_} \mathrm{N}\left(\mathrm{mg} \mathrm{g}^{-1}\right)$ & $0.53(0.21)$ & $0.58(0.25)$ & $1.87(0.07)$ \\
\hline Total N ( $\left.\mathrm{g} \mathrm{kg}^{-1}\right)$ & $1.88(0.08)$ & $2.59(0.06)$ & $2.07(0.04)$ \\
\hline Total $\mathrm{C}\left(\mathrm{g} \mathrm{kg}^{-1}\right)$ & $19.05(0.26)$ & $26.31(0.54)$ & $28.16(0.63)$ \\
\hline $\mathrm{C} / \mathrm{N}$ ratio & $10.12(0.29)$ & $10.17(0.06)$ & $13.62(0.05)$ \\
\hline
\end{tabular}

Values in parenthesis are standard deviations, $n=3$ land was planted to wheat which was at seedling stage at the time of sampling. The woodland (comprising mixed deciduous species) has been established for over 80 years.

Soil samples were stored immediately at $4{ }^{\circ} \mathrm{C}$ for 3 days before the start of the experiment. Six cores per land use were left intact within the rings used to collect them (intact core treatment) and the remaining six were sieved, moist, to $4 \mathrm{~mm}$, re-packed back into bulk density rings, and the residue on the sieve discarded. Each ring was placed in a 320-ml gastight jar customised to include a gas sampling port, and covered with Parafilm ${ }^{\circledR}$ to reduce moisture loss (but allow gas exchange) when not in use (Fig. 1). Six empty rings (without soil) were incubated in jars served as blanks similar to the method in Winkler et al. (1996) instead of a time zero measurement to correct for the initial flux. Samples were incubated at $10{ }^{\circ} \mathrm{C}$ for 45 days. The temperature was chosen to reflect the average temperature of topsoil (at $10 \mathrm{~cm}$ depth) in Reading, UK, between 1990 and 2017, which was $10.48^{\circ} \mathrm{C}$ (University of Reading, Meteorology Department Weather Station). The moisture contents in the soils were 21.6, 13.4 and $22.8 \%(\mathrm{w} / \mathrm{w})$ in arable, woodland and grassland, respectively. The moisture content of the soil in each jar was adjusted to $23 \%(\mathrm{w} / \mathrm{w})$ to maintain the set up at constant temperature and moisture. On days 1, 3, 17, 24, 31 and 38 after the start of the incubation, jars were sealed with a Suba-Seal® Septa for $1 \mathrm{~h}$ and a $10 \mathrm{ml}$ headspace gas sample was taken from each jar using a syringe and hypodermic needle, transferred into preevacuated Labco exetainers ${ }^{\circledR}$ vials and analysed with gas chromatography (Agilent 7890B). A 24-h pre-incubation was adopted, following the method in Meyer et al. (2019), but unlike the 14-day pre-incubation used in Comeau et al. (2018). A short pre-incubation prevents fast depletion of organic carbon, thereby preserving the carbon in near-field conditions. Moisture loss was corrected by gravimetric addition of deionised water after each gas sampling. The universal gas law was used to determine the amount of $\mathrm{CO}_{2}\left(\mu \mathrm{mol} \mathrm{CO} \mathrm{CO}_{2} / \mathrm{mol}\right.$ air) in our incubation jar; $\mu \mathrm{g} \mathrm{C}-\mathrm{CO}_{2}$ was calculated as $\mu \mathrm{g} \mathrm{C}$ $\mathrm{CO}_{2} \mathrm{~g}^{-1}$ soil $=\mathrm{mmol}$ air $\times \mathrm{ppm} \mathrm{CO} 2(\mu \mathrm{mol} \mathrm{C} / \mathrm{mol}$ air $) \times(10$ $3 \mathrm{~mol} / \mathrm{mmol}) \times(12 \mu \mathrm{g} \mathrm{C} / \mu \mathrm{mol} \mathrm{C}) /$ weight of oven-dried soil (g). Cumulative $\mathrm{CO}_{2}\left(\mu \mathrm{g} \mathrm{C}-\mathrm{CO}_{2} \mathrm{~g}^{-1}\right.$ soil) was calculated from the flux rate, as reported elsewhere (Lang et al. 2011), after deducting the blank $\mathrm{CO}_{2}$ concentration from each treatment. Prior to undertaking the experiment described above, we collected $\mathrm{CO}_{2}$ headspace gas from both the sieved and intact cores from each of arable, grassland and the woodland soils after incubation for 30, 60, 90 and $120 \mathrm{~min}$ to confirm a linear relationship between $\mathrm{CO}_{2}$ concentration and incubation time. Soil particle size distribution was measured using laser granulometry and converted from $\%$ volume to \% mass, as described elsewhere (Yang et al. 2015).

Soil characteristics, measured using standard laboratory methods, are presented in Table 1 . The particle size distribution of soils was determined using a Malvern Mastersizer 
Fig. 1 Diagram depicting experimental methodology
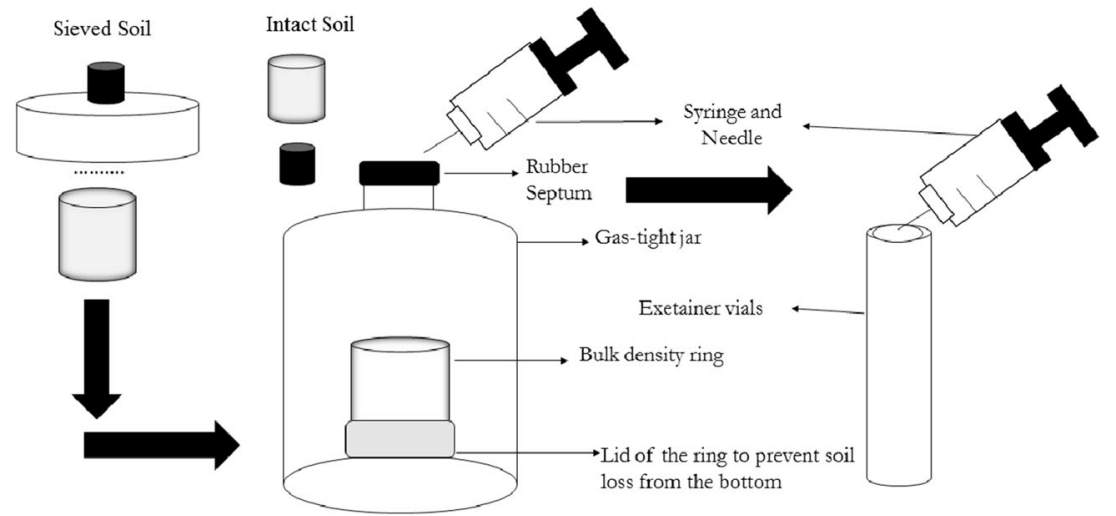

3000 Laser Granulometer after dispersing the soil in a solution containing $3.3 \%$ sodium hexametaphosphate $+0.7 \%$ sodium carbonate. Soil $\mathrm{pH}$ was determined by shaking soil samples with deionised water (1:2.5 mass/volume ratio) for $10 \mathrm{~min}$ and leaving the mixture to stand for $2 \mathrm{~min}$ before $\mathrm{pH}$ was measured using a digital type DMP-2 $\mathrm{mV} / \mathrm{pH}$ meter (Thermo Orion). Total $\mathrm{N}$ and $\mathrm{C}$ concentrations were determined using C/N Elemental Analyser (Thermo Flash 2000 EA). The C/N ratio was then calculated from total $\mathrm{C}$ and $\mathrm{N}$. Nitrate and ammonia were extracted in $1 \mathrm{M} \mathrm{KCl}$ and then analysed using Continuous Flow Analyzer ( $\mathrm{San}^{++}$Automated Wet Chemistry Analyzer - SKALAR). Moisture content and loss on ignition were determined by weight loss at $105^{\circ} \mathrm{C}$ and $500{ }^{\circ} \mathrm{C}$, respectively. Soil water holding capacity was determined using saturation and drain method by submerging a 30-g air-dried sample in a plastic cylinder with a mesh bottom in water for $12 \mathrm{~h}$ to ensure complete saturation and then allowing the water to drain for another $12 \mathrm{~h}$. The drained soil was then oven-dried at $105^{\circ} \mathrm{C}$ for $24 \mathrm{~h}$ and the dried weight recorded.

Repeated measures analysis of variance (ANOVA) was performed in Genstat (10th edition) to assess the variation in cumulative soil $\mathrm{CO}_{2}$ due to sieving and land use changes on different sampling days. Data showing negative fluxes were observed in one out of six replicates under disturbed grassland and were removed before the analysis. Correlations between the cumulative $\mathrm{C}-\mathrm{CO}_{2}$ flux and soil properties were explored.

\section{Results and Discussion}

The effect of soil sieving on cumulative $\mathrm{CO}_{2}$ flux is presented in Fig. 2. Repeated measures ANOVA revealed no significant effect of sieving on cumulative $\mathrm{C}-\mathrm{CO}_{2}(p>0.05)$, even though intact cores emitted more $\mathrm{CO}_{2}$ than sieved arable and grassland (but not woodland) soil. These observations challenge the assertion (Datta et al. 2014) that sieving soils stimulates a short-term $\mathrm{CO}_{2}$ flux, and our hypothesis that the decomposer soil microbial community under physically disturbed systems (e.g. arable soil) is more resistant to soil sieving compared with those of previously undisturbed systems (e.g. woodland soils). Performing our laboratory incubation study between 20 and $25{ }^{\circ} \mathrm{C}$ (which is often used in lab incubations) may result in different concentrations of $\mathrm{CO}_{2}$ reported, but we believe that the temperatures selected here best represent the

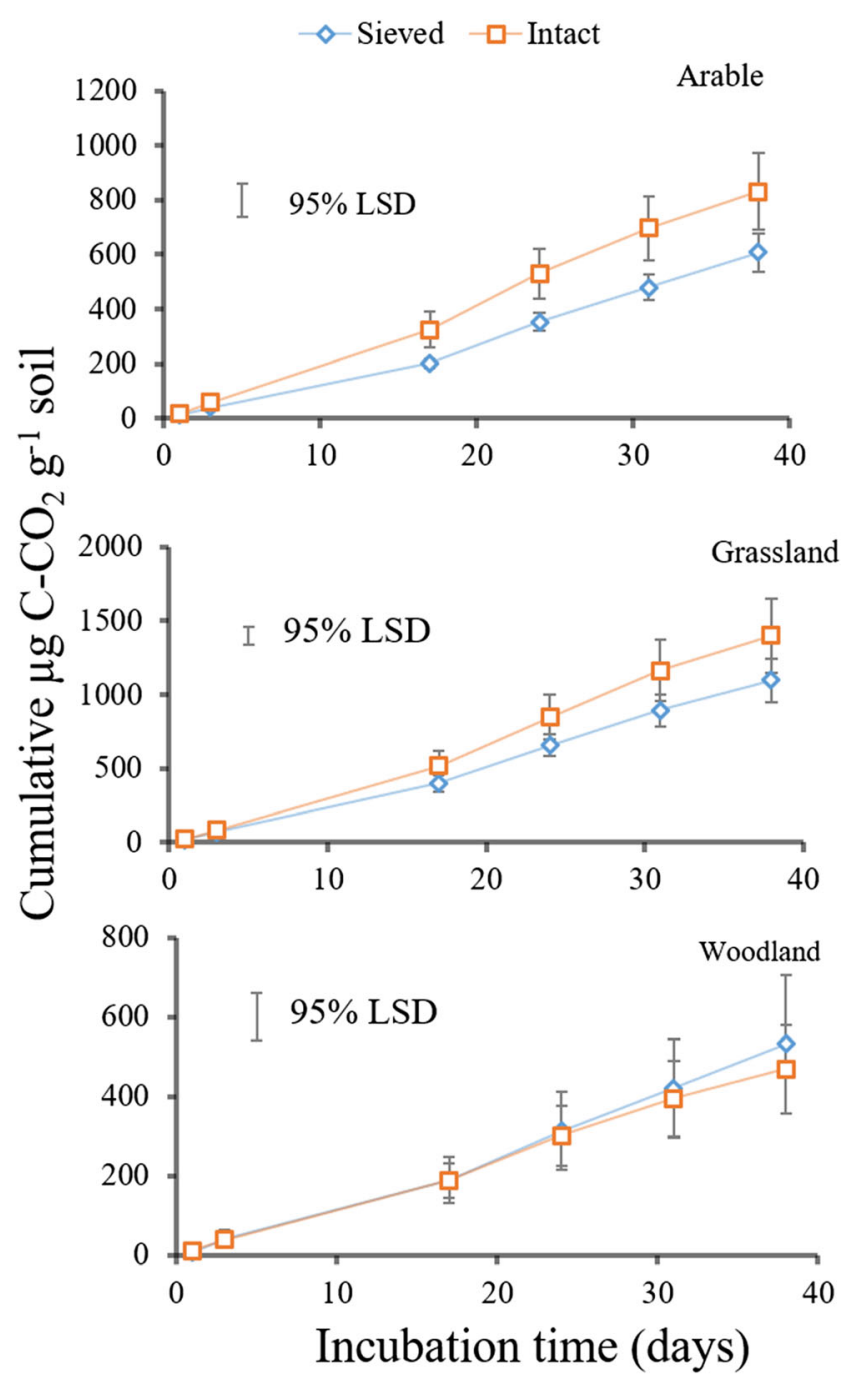

Fig. 2 Cumulative $\mathrm{CO}_{2}$ emissions of sieved soils and intact cores from arable, grassland and woodland soils. Error bars represent standard errors of mean, $n=6.95 \%$. LSD, least significant difference at the $95 \%$ level 
respiration of the soils in the field since we adopted the average daily mean soil temperature of the area from which the soils were collected. Our observations support the findings of others who also observe no significant difference in soil respiration between intact and sieved soils (Stenger et al. 2002; Thomson et al. 2010). However, the abovementioned studies analysed the effect of sieving on only pasture soils whereas soils from three different land use types are compared here in our experiment. Furthermore, the former (Stenger et al. 2002) reported only on the long-term (6 months) effect of sieving on soil respiration, while we report short-term effects in this study.

Although previous studies have shown that macroaggregates $(>0.25 \mathrm{~mm})$ can protect a small fraction of soil organic $\mathrm{C}$ from mineralisation, occlusion of $\mathrm{C}$ is likely to be more significant within microaggregates $(<0.25 \mathrm{~mm})$ that are present within the macroaggregates (Pulleman and Marinissen 2004). Our sieving treatment using a 4-mm mesh would only have disrupted the largest macroaggregates, leaving microaggregates intact. This phenomenon might explain why we obtained no significant effect of sieving on $\mathrm{CO}_{2}-\mathrm{C}$ flux. The use of a large $(4 \mathrm{~mm})$ mesh size for sieving also minimised the residue to be discarded to only an insignificant amount of small stones or woody material making the contents of the intact and sieved cores to be similar.

Clear differences were observed between soils from different land uses, irrespective of the sieving treatments. Cumulative $\mathrm{C}-\mathrm{CO}_{2}$ from grassland soil was $59.4 \%$ higher than woodland and $42.1 \%$ higher than arable soils, respectively. Similar results have been reported (Gutinas et al. 2013) where grassland soils emitted higher $\mathrm{CO}_{2}$ compared with arable and woodland after 42 days of incubation. However, our results contrast with an earlier study (Lang et al. 2011) which examined greenhouse gas emissions from forest and grassland soils and revealed that woodland soils emitted more $\mathrm{CO}_{2}$ than grassland soils, concluding that the global warming potentials of woodland soils are greater than those of grasslands.

The grassland soil had a higher water holding capacity, higher organic matter content, and lower $\mathrm{C} / \mathrm{N}$ ratio (Table 1 ), whereas the woodland soil had a higher total carbon content, but lower total nitrogen than the grassland and arable soil (resulting in a higher $\mathrm{C} / \mathrm{N}$ ratio). Thus, the differences in respiration between the three soil types could be explained by both the quantity and the stoichiometry of the organic matter. These differences can be further explained by considering the different water holding capacities of the three soils. All the soils were incubated at the same moisture content (23\%), but the woodland soil had a lower water holding capacity, compared with grassland and arable soils (Table 1). As a result, the grassland, arable and woodland soils were incubated at $41.4 \%, 46.6 \%$, and $56.2 \%$ of their respective water holding capacities, perhaps resulting in proportionally more waterfilled pores in the woodland soil. However, we found no significant correlation between the cumulative $\mathrm{C}-\mathrm{CO}_{2}$ flux and any soil properties, including water-filled pore space $\left(R^{2}=0.116 ; p=0.501\right)$.

\section{Conclusions}

Our experiment reveals that, although soil respiration varies with land use type, soil sieving has no significant impact on ex situ $\mathrm{CO}_{2}$ flux measurements. Thus, we conclude that soils sieved $(4 \mathrm{~mm})$ prior to ex situ respiration experiments provide realistic respiration measurements. However, we urge careful consideration when choosing a method of soil sampling and preparation prior to incubation for measuring soil respiration since both soil sieving and the use of intact cores have advantages and disadvantages. If soils are sieved prior to ex situ soil respiration measurements, then a soil sampling strategy that better accounts for the overall inhomogeneity of field conditions can more easily be adopted (since samples from multiple locations can be pooled, homogenised and assigned to treatments). While sieving may help in achieving multiple similar homogenous replicates, leading to increased reproducibility, incubation of soils in intact undisturbed cores better represents the soil architecture under field conditions. As a result of this understanding, and considering that the data shown were obtained for only three soils (arable, grassland and woodland from Sonning, England), our results provide evidence to help resolve an important dilemma for soil ecologists planning ex situ $\mathrm{CO}_{2}$ flux measurements to determine the influence of imposed treatments on soil respiration. However, we acknowledge that there could be different results obtained when using soils from geographical regions, land use types or soil management systems outside of those investigated in this study.

Acknowledgements Mike Charij is acknowledged for microcosm design, and Fengjuan Xiao is acknowledged for assistance with GC analysis.

Funding Information This work was funded by a Commonwealth Scholarship awarded to Adetunji Alex Adekanmbi.

Open Access This article is licensed under a Creative Commons Attribution 4.0 International License, which permits use, sharing, adaptation, distribution and reproduction in any medium or format, as long as you give appropriate credit to the original author(s) and the source, provide a link to the Creative Commons licence, and indicate if changes were made. The images or other third party material in this article are included in the article's Creative Commons licence, unless indicated otherwise in a credit line to the material. If material is not included in the article's Creative Commons licence and your intended use is not permitted by statutory regulation or exceeds the permitted use, you will need to obtain permission directly from the copyright holder. To view a copy of this licence, visit http://creativecommons.org/licenses/by/4.0/. 


\section{References}

Bao X, Zhu X, Chang X et al (2016) Effects of soil temperature and moisture on soil respiration on the Tibetan plateau. PLoS One 11: 9-15. https://doi.org/10.1371/journal.pone.0165212

Baveye PC, Otten W, Kravchenko A, Balseiro-Romero M, Beckers É, Chalhoub M, Darnault C, Eickhorst T, Garnier P, Hapca S, Kiranyaz S, Monga O, Mueller CW, Nunan N, Pot V, Schlüter S, Schmidt H, Vogel HJ (2018) Emergent properties of microbial activity in heterogeneous soil microenvironments: different research approaches are slowly converging, yet major challenges remain. Front Microbiol 9:1929. https://doi.org/10.3389/FMICB.2018.01929

Comeau LP, Lai DYF, Jinglan Cui J, Farmer J (2018) Separation of soil respiration: a site-specific comparison of partition methods. Soil 4: 141-152. https://doi.org/10.5194/soil-4-141-2018

Datta R, Vranová V, Pavelka M et al (2014) Effect of soil sieving on respiration induced by low-molecular-weight substrates. International Agrophysics 28:119-124. https://doi.org/10.2478/ intag-2013-0034

Davidson EA, Belk E, Boone RD (1998) Soil water content and temperature as independent or confounded factors controlling soil respiration in a temperate mixed hardwood forest. Glob Chang Biol 4:217227. https://doi.org/10.1046/j.1365-2486.1998.00128.x

Gabriel CE, Kellman L (2011) Examining moisture and temperature sensitivity of soil organic matter decomposition in a temperate coniferous forest soil. Biogeosci Discuss 8:1369-1409. https://doi.org/10. 5194/bgd-8-1369-2011

Gutinas ME, Gil-Sotres F, Leiros MC, Trasar-Cepeda C (2013) Sensitivity of soil respiration to moisture and temperature. J Soil Sci Plant Nutr 13:445-461. https://doi.org/10.4067/S071895162013005000035

Hangs RD, Ahmed HP, Schoenau JJ (2016) Influence of willow biochar amendment on soil nitrogen availability and greenhouse gas production in two fertilized temperate prairie soils. Bioenergy Research 9: 157-171. https://doi.org/10.1007/s12155-015-9671-5

Herbst M, Tappe W, Kummer S, Vereecken H (2016) The impact of sieving on heterotrophic respiration response to water content in loamy and sandy topsoils. Geoderma 272:73-82. https://doi.org/ 10.1016/j.geoderma.2016.03.002

Lang M, Cai Z, Chang SX (2011) Effects of land use type and incubation temperature on greenhouse gas emissions from Chinese and Canadian soils. J Soils Sediments 11:15-24. https://doi.org/10. 1007/s11368-010-0260-0

Marland G (2008) Uncertainties in accounting for CO2 from fossil fuels. J Ind Ecol 12:136-139. https://doi.org/10.1111/j.1530-9290.2008. 00014.x

Mathur SP, Sanderson RB (1978) Relationships between copper contents, rates of soil respiration and phosphatase activities of some Histosols in an area of southwestern Quebec in the summer and the fall. Can J Soil Sci 58:125-134. https://doi.org/10.4141/cjss78-016

McGowen EB, Sharma S, Deng S, et al (2018) An automated laboratory method for measuring $\mathrm{CO}$ emissions from soils. Agricultural \& Environmental Letters 3:0. doi: https://doi.org/10.2134/ael2018.02. 0008

Meyer N, Welp G, Amelung W (2019) Effect of sieving and sample storage on soil respiration and its temperature sensitivity (Q10) in mineral soils from Germany. Biol Fertil Soils 55:833. https://doi.org/ 10.1007/s00374-019-01380-9

Pulleman MM, Marinissen JCY (2004) Physical protection of mineralizable $\mathrm{C}$ in aggregates from long-term pasture and arable soil. Geoderma 120:273-282. https://doi.org/10.1016/j.geoderma.2003. 09.009

Schurgers G, Ahlström A, Arneth A et al (2018) Climate sensitivity controls uncertainty in future terrestrial carbon sink. Geophys Res Lett 45:4329-4336. https://doi.org/10.1029/2018GL077528

Stenger R, Barkle GF, Burgess CP (2002) Mineralization of organic matter in intact versus sieved/refilled soil cores. Australian Journal of Soil Resources 40:149-160

Thomson BC, Ostle NJ, McNamara NP, Whiteley AS, Griffiths RI (2010) Effects of sieving, drying and rewetting upon soil bacterial community structure and respiration rates. J Microbiol Methods 83:69-73. https://doi.org/10.1016/j.mimet.2010.07.021

Thuries L, Larre-Larrouy MC, Pansu M (2000) Evaluation of three incubation designs for mineralization kinetics of organic materials in soil. Commun Soil Sci Plant Anal 31:289-304

Valerie OA, Cook FJ (1983) Pollution control and resource recovery: municipal solid wastes at landfill. Soil Biol Biochem 15:447-453

Winkler JP, Cherry RS, Schlesinger WH (1996) THE Q ,, Relationship of microbial respiration in a temperate forest soil A " bey ; R ; . 28: 1067-1072

Yan D, Li J, Pei J, Cui J, Nie M, Fang C (2017) The temperature sensitivity of soil organic carbon decomposition is greater in subsoil than in topsoil during laboratory incubation. Sci Rep 7:1-9. https://doi. org/10.1038/s41598-017-05293-1

Yang X, Zhang Q, Li X et al (2015) Determination of soil texture by laser diffraction method. Soil Sci Soc Am J. https://doi.org/10.2136/ sssaj2015.04.0164

Zhou W, Hui D, Shen W (2014) Effects of soil moisture on the temperature sensitivity of soil heterotrophic respiration: a laboratory incubation study. PLoS One 9. https://doi.org/10.1371/journal.pone. 0092531

Publisher's note Springer Nature remains neutral with regard to jurisdictional claims in published maps and institutional affiliations. 